\title{
On Altı Yaşında Bir Kız Hastada Görülen Nadir Bir Ürogenital Miyazis Olgusu
}

\author{
A Rare Case of Urogenital Miasis in a Sixteen-Year-Old Girl
}

\author{
Zeynep SAVAŞ ŞEN, Meltem POLAT
}

SBÜ, Dr. Sami Ulus Kadın Doğum, Çocuk Sağlığı ve Hastalıkları EAH, Çocuk Enfeksiyon Kliniği, Ankara, Türkiye

\begin{abstract}
öz
Miyazis, diptera takımına ait sinek larvalarının insanların ve omurgalı canlıarın canlı veya ölü dokularına yerleșmesi sonucu oluşan parazitik bir hastalıktır. Larvalar cilt yaraları veya ağız, kulak, göz ve ürogenital sistemden vücuda girerler. Bazı bölgelerde endemik iken diğer yerlerde seyahat ilişkilidir. İnsan miyazisi için bildirilen risk faktörleri arasında kötü hijyen, ileri yaş, diabetes mellitus, psikiyatrik hastallk, kırsal bölgede yaşama, düşük sosyoekonomik koşullar ve evsizlik bulunmaktadır. Psychoda albipennis nemli banyolarda çoğalarak insanda ürogenital miyazise neden olabilir. Burada 16 yaşında, tip 1 diabetes mellitus tanısı olan bir kız hastada P.albipennis' in neden olduğu nadir bir ürogenital miyazis olgusu sunulmuştur. Sonuç olarak ürogenital miyazis ülkemiz koşullarında kırsal alanda yaşayan, kötü hijyenik koşulları olan ve idrarında kurt görme șikayeti olan hastalarda unutulmaması gereken bir hastalıktır.
\end{abstract}

Anahtar Sözcükler: Çocuk, Miyazis, Ürogenital

\begin{abstract}
Myiasis which is a parasitic disease of humans and vertebrates, is caused by dipterous fly larvae feeding on the host's necrotic or living tissue. Entry of the larvae occurs through skin wounds or mouth, ears, eyes and urogenital tract. The infestation is endemic in some areas and travel-related in other areas. The reported predisposing risk factors for human myiasis include poor hygiene, advanced age, diabetes mellitus, pyschiatric illness, low socio-economic status and homelessness. Psychoda albipennis which can thrive in an environment of a moist bathroom may cause urogenital myiasis in humans. Here, we reported a rare case of urogenital myiasis caused by $P$. albipennis in a 16 year-old female patient with type 1 diabetes mellitus. In conclusion, urogenital myiasis should be kept in mind in patients who are living in rural areas, having poor hygienic conditions and see worms in their urine.
\end{abstract}

Key Words: Child, Myiasis, Urogenital

\section{GiRiş}

Miyazis, diptera takımına ait sinek larvalarının omurgalı canlıların (hayvanlar ve insanlar) canlı veya ölü dokularına yerleșmesi sonucu oluşan parazitik bir hastalıktır. Larvalar cilt yaraları veya ağız, kulak, göz ve ürogenital sistemden vücuda girebilirler. Bazı bölgelerde endemik iken diğer yerlerde seyahat ilişkilidir. Insan miyazisi için bildirilen risk faktörleri arasında kötü hijyen, ileri yaş, diyabet, psikiyatrik hastalık, kırsal bölgede yaşama, düşük sosyoekonomik koşullar ve evsizlik bulunmaktadır (1). Miyazis insanlarda deri, akciğer, nazofarinks, göz, kulak, mide, rektum, barsak ve ürogenital miyazis olarak sınfflandırıı. Kapalı bölge olması ve iç çamaşırı giyilmesi nedeniyle genital bölgeye sineklerin larva bırakması güçtür ve bu nedenle ürogenital miyazis nadir görülmektedir (2). Psychoda albipennis nemli banyolarda çoğalarak insanda ürogenital miyazise neden olabilir. Genelde yaz aylarında tropikal ve subtropikal bölgelerde görülür ve çoğunlukla erişkinlerde bildirilmiştir (3). Burada 16
(1)

SAVAȘ ȘEN Z : 0000-0003-4671-6082 POLAT M : 0000-0002-4608-1286
Çıkar Çatışması / Conflict of Interest: : Tüm yazarlar adına, ilgili yazar çıkar çatışması olmadığını belirtir.

Finansal Destek / Financial Disclosure: Yazarlar bu olgu için finansal destek almadıklarını beyan etmișlerdir.

Onay / Confirmation: Kayıt sırasında veliler tarafından araştırmaya katııı için bilgilendirilmiş bir onay imzalanmıştır.

Atıf yazım șekli / How to cite : Savaș Şen Z, Polat M. On Altı Yaşında Bir Kız Hastada Görülen Nadir Bir Ürogenital Miyazis Olgusu. Türkiye Çocuk Hast Derg 2021;15:248-250.
Yazıșma Adresi / Correspondence Address:

\section{Zeynep SAVAȘ ŞEN}

SBÜ, Dr. Sami Ulus Kadın Doğum, Çocuk Sağlığı ve Hastalıkları EAH,

Çocuk Enfeksiyon Kliniği, Ankara, Türkiye

E-posta: zeysa81@gmail.com
Geliş tarihi / Received : : 30.06.2020 Kabul tarihi / Accepted : 10.09.2020 Elektronik yayın tarihi $\quad$ : 26.01.2021 Online published

DOI: 10.12956/tchd.760398 
yaşında, tip 1 diabetes mellitus tanısı olan bir kız hastada $P$. albipennis adlı sinek türünün neden olduğu nadir bir ürogenital miyazis olgusu sunulmuştur.

\section{OLGU SUNUMU}

16 yaşında kız hasta 1 aydır olan dizüri, sık idrara çıkma, genital bölgede kaşıntı ve idrarında kurt görme şikayetleri ile pokliniğimize başvurdu. Hastanın öyküsünden, Tip 1 diabetes mellitus hastası olduğu ancak diyet ve insülin tedavisine uyum göstermediği için kan şekerinin yüksek seyrettiği öğrenildi. Benzer şikayetlerle 2 hafta önce farklı bir merkeze başvuran hastaya, Enterobius vermicularis ön tanısı ile albendazol tedavisi verildiği ancak şikayetlerinde düzelme olmadığı saptandı. Başvuru esnasındaki fizik muayenesinde vücut ısısı $36.7^{\circ} \mathrm{C}$, kalp tepe atımı 76/dakika, solunum sayısı 24/dakika, kan basıncı 110/70 mmHg'di. Genital hijyen bozukluğu ve kötü kokulu vajinal akıntısı mevcuttu. Laboratuvar incelemesinde tam idrar tetkikinde glukozüri, biyokimya tetkikinde kan şekeri 280 mg/dl olarak saptandı. Hemogram, akut faz reaktanları ve dışkı mikroskopisi normal olarak bulundu. İdrar kültüründe üreme olmadı. Hastanın idrarında görülen larvaların parazitolojik incelemesi sonucunda P.albipennis adlı sineğin 4. dönem larvaları (Resim 1) saptandı. Hastanın öyküsü derinleştirildiğinde banyolarında sineklerin olduğu öğrenildi. Apartman dairesinde oturan hastanın evlerinde tek tuvalet mevcuttu. Sineklerle mücadele için herhangi bir işlem yapılmamıştı. Ailedeki diğer bireylerin şikayeti olmaması nedeni ile idrar tetkiki yapılma gereği duyulmadı. Hastanın yatırılarak kan şekeri regülasyonu yapıldı ve üriner sistemden larvaların atıımını sağlamak için bol hidrasyon uyguland. Bir hafta içinde şikayetleri gerileyen hastaya antiparaziter tedavi verilmedi.

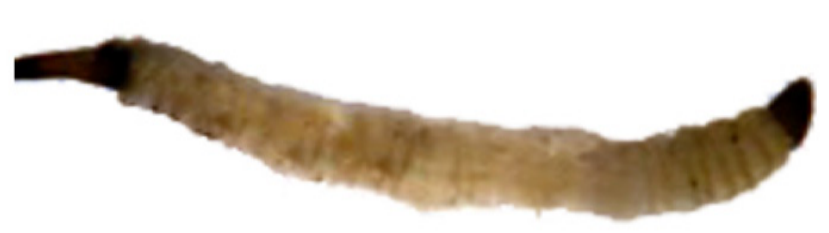

Resim1: Psychoda albipennis adlı sineğin 4. dönem larvaları.

\section{TARTIŞMA}

Ürogenital miyazis Sarcophaga spp., Megaselia scalaris, Thyrsocnema incisilobata, Lucilia sericata, Eristalis tenax, Dermatobia hominis, Chrysomya bezziana, Fannia canilicularis, ve Psychoda albipennis'in neden olduğu nadir görülen klinik bir durumdur. P.albipennis'in Avrupa ve Çin'in ılıman bölgelerinde bulunduğu bilinmektedir (3). Türkiye'de Ankara, Edirne, Tekirdağ, Bursa ve İstanbul'dan bildirilen vakalar vardır (4). P. albipennis, Pyschodidae ailesi Psychodinae alt ailesinden drenaj, banyo ve filtrelerin sinekleri olarak bilinen ilkel bir Nematocera'dır. Larvaları gri-beyaz renkte olup yaklaşık 3-5 mm boyutundadır.Ön kısımları arkaya göre daha ince, kurtçuk şeklinde ve hafif yassı bir görünüme sahiptir. Vücutları kısa tüy veya pullarla kaplıdır ve bazen kenarlarında diş benzeri yapılar bulunabilir. Larvalar genelde nemli ve kirli alanlarda, çöp yığınlarında ve larvaların hayatta kalabilmesi için bol miktarda bakteri bulunan sulama kanallarında bulunur (5). Uygun koşullarda larva evresi 6 ile 8 gündür, ancak soğuk havalarda veya yiyeceklerde, 4-5 hafta veya daha fazla sürebilir (2). Dördüncü dönem larvalar insan idrarını enfekte edebilir. Ürogenital miyazis, nadir olmakla birlikte tropikal bölgelerde ve özellikle de kötü hijyene sahip kırsal alanlarda sık görülmektedir. Parazit yaşam döngüsünü insan vücudunda tamamlamamaktadır. Bu nedenle hasta hijyenik koşullara ve temizliğe dikkat ettiğinde yeniden enfeksiyon görülmez (5). Bizim olgumuzda kontrolsüz diabetes mellitus tanısının olmasının ve hijyeninin bozuk olmasının ürogenital miyazise yatkınlık yaratmış olduğunu düşünmekteyiz.

Ürogenital miyazis ile ilgili bir derlemede Türkiye'deki 12 vakanın (10'u üriner, 1'i penil, 1'i vulvar miyazis) 7'sinde (\%58.3) etkenin P. albipennis olduğu gösterilmiştir (6). Ülkemizde miyazis en fazla yaz ve sonbahar mevsiminde görülmektedir. Yatağa bağımlı hareketsiz hastalar, yaz aylarında üzeri açık uyuyan çocuk ve erişkinler sineklerin yumurtalarını genital bölgeye ve perineye bırakma riskine açıktırlar (7). Ülkemizde P.albipennis nedenli erişkin ürogenital miyazis olguları bildirilmiştir $(3,6,7)$. Çocuklarda $P$. albipennis'e bağlı ürogenital miyazis çok daha nadirdir ve ülkemizden biri 10 yaşında kız, diğeri 15 yaşında erkek olmak üzere iki çocuk olgu bildirilmiştir $(4,8)$.

Hastalığın semptomlarının spesifik olmaması ve nadir görülmesi yanlış tanı konulmasına neden olabilmektedir. Hastalarda karın ağrısı, bulantı, kaşıntı, rektal kanama, kusma, yan ağrısı gibi genel semptomların yanısıra dizüri, pollaküri, hematüri ve idrarda larva görülmesi gibi spesifik semptomlar bulunabilir. Bazı olgularda tek bulgu idrarda sinek larvalarının görülmesi olabilmektedir. Özellikle çocuk olgularda bizim hastamızda olduğu gibi miyazis vakalarına yanlışlıkla Enterobius vermicularis tanısı konulduğu ve antiparaziter tedavi verildiği bildirilmiştir (4). Enfeksiyonun spesifik bir tedavisi bulunmamaktadır. Tedavide hijyen koşullarının düzeltilmesi ve larvaların mekanik olarak uzaklaştırılması önerilmektedir $(1,3,5)$. Hastamızda 
bol hidrasyon, kan şekeri regülasyonu ve hijyen koşullarının düzeltilmesi ile düzelme sağlanmıştır.

\section{SONUÇ}

Ürogenital miyazis çocuklarda nadiren bildirilmiştir. Semptomlarının spesifik olmaması ve hekimler tarafindan iyi bilinmemesi nedeniyle tanısında zorluklar yaşanmaktadır. Burada 16 yaşında, hijyenik koşulları kötü ve kontrolsüz tip 1 diabetes mellitus tanısı olan bir kız hastada nadir bir ürogenital miyazis olgusu sunulmuştur. Hastamıza başlangıçta yanlış E.vermicularis tanısı konularak albendazol tedavisi başlanmış ancak şikayetlerinde düzelme olmaması üzerine idrarında görülen larvaların mikroskopik incelemesi ile P.albipennis'in neden olduğu ürogenital miyazis tanısı konulmuştur. Kötü hijyenik koşullarda ve sineklerin bulunduğu kırsal alanlarda yaşayan hastalarda idrarda kurt görme şikayeti ile başvuran ve antiparaziter tedaviye yanıt alınamayan hastalarda ayıııc tanıda ürogenital miyazis de düşünülmelidir.

\section{KAYNAKLAR}

1. Faridnia R. Soosaraei $M$, Kalani $H$, Fakhar $M$, Jokelainen $P$, Emameh RZ, et al. Human urogenital myiasis: A systematic review of reported cases from 1975 to 2017. Eur J Obstet Gynecol Reprod Biol 2019; 235: 57-61.

2. Rasti S, Dehghani R, Naeimi Khaledi H, Takhtfiroozeh SM, Chimehi E. Uncommon Human Urinary tract Myiasis Due to Psychoda Sp. Larvae, Kashan, Iran: A Case Report. Iran J Parasitol 2016;11: 417-21.

3. Culha MG, Turker K, Ozsoy S, Seferoglu EC. Urogenital myiasis caused by Psychoda albipennis. Saudi Med J 2016; 37:1401-3.

4. Doğan Demir A, Iraz M, Sayın İpek DN. Urogenital myiasis caused by Psychoda albipennis in a child. Turkish Archives of Pediatrics 2015; 50: 65-8.

5. Shimpi R, Patel D, Raval K. Human urinary myiasis by Psychoda albipennis: A case report and review of literature. Urology case reports 2018; 21:121-3.

6. Singh A, Kaur J. Occurrence of human urogenital myiasis due to neglected personal hygiene: a review. Trans R Soc Trop Med Hyg 2018; 00:1-7.

7. Yenice MG, Demir T, Babür C, Nalbantoğlu S, Kılıç S. Psychoda albipennis'in (Diptera: Nematocera) Neden Olduğu Ürogenital Miyazis Olgusu. Mikrobiyoloji bülteni 2011;3:558-64.

8. Çiçek M, Diker Al, Sayın Ijpek DN, Tekin A, Dal T. Psychoda albipennis' in Sebep Olduğu Bir Ürogenital Myiasis. Turkiye Parazitol Derg 2012; 36:51-3. 